\title{
Particularities of reproduction and oogenesis in teleost fish compared to mammals
}

\author{
Bernard JALABERT* \\ Groupe «Sexualité et Reproduction des Poissons », Institut National de la Recherche Agronomique, \\ SCRIBE, Campus de Beaulieu, 35042 Rennes Cedex, France
}

\begin{abstract}
Compared to mammals, teleost reproduction presents many original features. Reproductive strategies of species are diversified into numerous adaptations to a large variety of aquatic environments. This diversity may concern sexuality, spawning and parental behaviour, sensitivity to environmental factors, and specific features of gametogenesis such as the duration of vitellogenesis, and egg morphology. Sexuality presents a variety of natural modalities, from gonochorism to hermaphrodism. The absence of definitive arrest of body growth in the adult of most species gives a particular interest to the practical control of growth-reproduction interactions. Vitellogenesis, which represents an important metabolic effort for the maternal organism, involves the synthesis of vitellogenin, a specific glycolipo-phosphoprotein produced in the liver under estradiol stimulation, and its incorporation into oocytes by a receptor mediated process. Both estradiol synthesis in follicle cells and vtg uptake by vitellogenic follicles appear to be mainly controlled by FSH. Oocyte maturation is directly triggered by a progestin, or MIS (maturation inducing steroid) synthesised in follicle cells mainly under LH control, and acting through the non-genomic activation of a membrane receptor. Practical applications of some of these particularities result mainly from the external character of the fertilisation process and of embryonic development, which allows manipulating respectively egg chromosome stocks and sex differentiation. Moreover, the sensitivity of sex differentiation to exogenous factors favours the development of practical methods to control the sex of farmed populations. Finally, the sensitivity of reproductive mechanisms to xenobiotics has led to various kinds of bioassays for putative pollutants.
\end{abstract}

reproductive strategies / sexuality / spawning / vitellogenesis / oocyte maturation / fertilisation

\section{INTRODUCTION}

Modes of reproduction in fishes offer an extreme diversity related to the great number of species (about 28700, according to FishBase: www.fishbase.org), and to the large variety of aquatic environments inhabited. This resulted in numerous adaptations also called "reproductive strategies" [1]. Of course, such a natural diversity is very interesting for comparative biology. But it also contains numerous biological models, some of which are particularly convenient to acquire physiological or genetic knowledge of general interest in vertebrates, and some other more convenient to develop fish farming systems. Professor Charles Thibault was probably highly conscious of these ideas,

* Corresponding author: Bernard.Jalabert@rennes.inra.fr 
Table I. World evolution of finfish aquaculture production compared to total aquaculture, total fisheries, and total terrestrial animals, from 1970 to 2000 (million metric tons) (source: FAO).

\begin{tabular}{lccc}
\hline & 1970 & 2000 & Coefficient \\
\hline Terrestrial animals & 100 & 235 & $* 2.35$ \\
Total fisheries & 66 & 96 & $* 1.45$ \\
Total aquaculture & 3.5 & 46 & $* 13.1$ \\
Cultured finfishes & 1.5 & 23 & $* 15.3$ \\
\hline
\end{tabular}

thirty-five years ago, when he decided to draw up a state of knowledge in the field of fish reproductive physiology as a part of a university course. Thus noticing an obvious lack of knowledge at that time, he strongly contributed to develop in INRA a research group in that field. Since that time, a considerable number of research works has also accumulated in the world. Fishes became biological models for various scientific disciplines [2]. On the other hand, the world production of cultured fish exhibited a tremendous rise (Tab. I). All this shows that the initiative taken by professor Thibault was in fact a precursor enterprise. The present paper does not intend to reach exhaustivity in a field now so wide. It is only aimed at bringing out some particularities of reproduction in fishes compared to mammals. Therefore, it will give a brief overview of various reproductive strategies, then it will focus on some original points about teleost oogenesis, and finally it will give some examples of applications to the control of reproduction in fish farming. Bibliographic references will be preferentially chosen among original works from the research groups that were initially established by Professor Charles Thibault.

\section{MAIN PARTICULARITIES OF FISH REPRODUCTION}

\subsection{Sexuality}

Reproductive strategy diversity first concerns sexuality, which shows numerous natural variants, from strict gonochorism to simultaneous functional hermaphroditism. [3-5].

Gonochorism can even be underlied by a more or less tight genetic determinism. In fact, only some species exhibit morphologically differentiated sex chromosomes [6]. In the others, male or female heterogamety was first deduced from results of back crossing individuals obtained by hormonal sex reversion [7], like in tilapias Oreochromis mossambicus [8] and O. niloticus [9], or from artificial gynogenesis like in rainbow trout Oncorynchus mykiss [10]. In tilapias belonging to the genus Oreochromis, the heterogametic sex may be either the male or the female depending on the species. This may explain why crossing homogametic males from one species with homogametic females from the other can give monosex male F1 offspring, an interesting result for tilapia fish farming since monosex male populations are expected to express a better growth rate without growing in number [11]. However, sex-ratio results from the back crosses between $F 1$ and parent species suggest that the genetic determination system might not be so simple $[9,11]$. Recent data actually confirm that sex chromosomes of $O$. niloticus, although identified by in situ hybridation techniques, are still weakly differentiated $[12,13]$, and that sex determining genes can be localised on other chromosomes [14]. In salmonids, where the male is generally considered as the heterogametic sex, the determining locus can be situated on different chromosomes depending on the species [15], and other loci can also play a role [16]. Such weak differentiation of sex chromosomes may probably explain that viable abnormal new genotypes YY can be obtained relatively easily through various procedures, such as autofertilisation in hermaphroditic rainbow trout obtained by estrogenic treatment [17].

Moreover, the phenotypic sex in some gonochoric species appears to result from interactions between genetic and environmental factors during gonad differentiation 
[5]. Thus, among farmed species, sex-ratio deviations in favour of males can be observed in tilapia $O$. niloticus and atipa Hoplosternum littorale [18] exposed to a high incubation temperature [19], and in sea bass Dicentrarchus labrax submitted to complex interactions between temperature $[20,21]$ and probably other factors associated with juvenile farming stages [22]. In both cases, the sensitivity to environmental factors appear to exhibit a strong genetic component.

Finally, another particularity of sex differentiation in fishes compared to mammals is that exogenous steroid treatments, administered during gonad differentiation through either balneation or food, are relatively efficient to obtain functional sexreversed fishes. Such an ability, which was first demonstrated in various aquarium species [4], was further developed for experimental purposes [5] and even for fish farming when rearing monosex populations is economically advantageous [23].

Concerning hermaphroditism, numerous variants of this strategy and underlying mechanisms have been extensively reviewed $[3,5,24]$. The most current is successive hermaphroditism. This can be protandrous, when the fish breeds as a functional male during the first part of the life cycle, before undergoing sex inversion to breed as a female during the second part. Among cultured species, this is the case of barramundi, Lates calcarifer [25], and of numerous sparid fish such as the sea-bream [26] and red porgy Pagrus pagrus [27]. Protogynous hermaphroditism is particularly frequent among serranid fish, especially groupers [28]. Simultaneous hermaphroditism is characterised by the development of testicular and ovarian parts that reach maturity at the same time within the gonads of the same fish. It can be found in some serranid species from coral reefs, but occurrence of self fertilisation is exceptional because each partner alterns its sexual role and successively releases eggs and sperm in turn along successive spawning sequences [29]. In most hermaphroditic species, age and size of sex inversion can be strongly influenced by environmental factors in a wide sense, i.e. including social interactions, and particularly by the sex ratio within a fish group. Finally, the occurrence of simultaneous hermaphroditism with self fertilization was discovered in a species of the tropical mangrove, Rivulus marmoratus [30]. In this species, however, some males can be exceptionally found with a low frequency which can be artificially increased by exposition to lower temperatures than normal (19.5 instead of 25) during development [31]. In fact, this seems to be the case in various populations of this species, some of which have been shown to be distinct homozygous strains, whereas some outcrossing might occur in the others, due to the occasional presence of some males. Such outcrossing is suspected to have evolved as a phenotypically plastic character, and its expression in $R$. marmoratus has been suggested to be dormant unless triggered by some ecological factor that is not well understood [32].

Finally, the occurrence in some species of sex strategies which have been described as "degraded" must be mentioned [33]. This is the case of natural gynogenesis and hybridogenesis that have been exhaustively reviewed [34]. The "Amazon molly", Poecillia formosa, is a famous well known example of natural gynogenesis [35]. This species is structured into a limited number of clones [36], diploid in general, or more rarely triploid. Reproduction depends on the activation of oocytes by the spermatozoa from sympatric close-related species. As a result of the suppression of normal mechanisms of meiosis [37], oocytes are either diploid or triploid, depending on clones, and they are holding the same genotype as the mother. This species has been suggested to result from an initial hybridation event [38]. Other examples of natural gynogenesis are known, such as two subspecies of Carassius auratus, the gibelio Carassius auratus gibelio (China and Eastern Europe), and the gimbuna Carassius auratus langsdorfii (Japan) which exist as 
triploid, usually monosex, female populations. In gimbuna, at least two meiosis anomalies can explain this mode of reproduction: the formation of an abortive tripolar spindle in place of the first meiotic division [39], and the unability of oocytes to promote the nuclear envelope breakdown of the spermatozoa, which cannot be transformed into a male pronucleus after activating the oocyte [40]. Another case of special sexual strategy is hybridogenesis with a well known example in the genus Poeciliopsis [41]. This strategy allows an actually hybrid all-female population, in which both parental genomes are co-expressed at the somatic level, to persist by way of a non recombinant meiosis that selectively discard one parental genome. Thus, the back cross with males of one parental species gives normal individuals of this species, while the back cross with the other species again produces the hybrid species.

Such diversity is potentially rich of situations especially convenient for the unscrambling of mechanisms common to all vertebrates. For example, the availability of two different strains of gibelio, one gonochoristic with a normal first meiotic division, and the other gynogenetic, with a first meiotic division inhibited, appeared convenient to try to identify genes differentially expressed in fully-grown oocytes of both populations [42]. This allowed finding differential expression of four genes, out of which two were novel genes. The others were histone $\mathrm{H} 2 \mathrm{~A}$, and cyclin $\mathrm{A} 2$. The mRNA of the last were found to be stored in much higher amounts in oocytes of the gynogenetic strain than in the gonochoristic strain.

\subsection{Reproductive and parental behaviour - spawning and fertilisation}

Reproductive behaviours in the wild are also widely diversified, from collective pelagic spawning without any egg care, up to sophisticated sexual behaviours eventually involving nest building, and followed by parental cares to eggs and fry. Fertilisation is the more often external, after almost simultaneous release of eggs and sperm during spawning. Only some examples will be given here, mainly taken among cultured species. Pelagic spawning concerns species like cod Gadus morhua [43], or sea-bass Sparus aurata that annually spawn a very large number of small floating eggs. The eggs of various freshwater species are laid surrounded by an external sticky layer, like the common carp Cyprinus carpio [44], and some silurid species such as the African catfish Clarias gariepinus [45]. Such eggs are pasted upon aquatic plants, floating debris, or any kind of immersed substrate where they are left after spawning. Salmonids deposit large sized demersal eggs in a gravel tough excavated by tail movements of the female and leave them without additional care. Some farmed silurids like Ictalurus punctatus in America and Chrysychtys nigrodigitatus in Africa spawn within sheltered cavities where both parents take care of the eggs and embryos during the incubation period. The male of another silurid, the atipa Hoplosternum littorale in tropical South America, builds a floating nest made of vegetal debris and mucus bubbles where eggs are deposited and bitterly defended against intruders [46]. Finally, in tilapias of the genus Oreochromis, the male digs a funnel-shaped nest on the bottom with its mouth. In the course of several repeated spawning sequences, successive egg clutches are laid by the female, covered with a ribbon of sperm by the male, and then taken in the mouth by the female. She will keep the embryos continuously within the buccopharyngeal cavity during a first period of 15 days (at $\sim 27{ }^{\circ} \mathrm{C}$ ) of embryo development, thus ceasing to feed, then liberating the young fry temporarily for increasing periods, up to definitive release at the end of larval development [47]. In that species exhibiting repeated successive reproductive cycles of about one month, mouth brooding behaviour is closely related to the rhythm of ovarian development [48] and endocrine profiles of growth hormone, prolactin 
(PRL) and sex steroids [49]. In tilapias belonging to the genus Sarotherodon, mouth brooding is normally performed by the male, but the female can occasionally participate [50]. Although an implication of PRL in the regulation of maternal behaviour has been suggested in various fish species, no definitively convincing evidence has been brought so far.

In particular instances among teleost species, fertilisation can be internal, for instance in some silurids [45] or well known viviparous cyprinodontiforms like the mosquito fish, Gambusia affinis, or the guppy, Poecilia reticulata. In the latter, males exhibit a gonopodium resulting from the modification of several anal fin rays into a kind of erectile gutter which allows discharging sperm clusters, or spermatozeugmata, into the female genital papilla [51]. Spermatozoa get through the oviduct into the ovarian cavity where they can retain their fertilising ability for several months. Storage sites are either a seminal receptacle formed by an extension of the antero-dorsal region of the ovarian cavity, where spermatozoa are inserted into specialised cells presenting an astonishing ultrastructural analogy with testis Sertoli cells [52], or knob-shaped micropockets expanding from the ovarian cavity to the follicle surface which are probably the sites of sperm entry at fertilisation time [53]. Oocyte maturation is not followed by ovulation, but by intrafollicular fertilisation with spermatozoa released from storage sites. Embryo development also occurs inside the follicles, up to parturition of fully developed fry.

\subsection{Importance of environmental factors}

The role of environmental factors in the control of fish reproductive cycles has been reviewed in several papers, out of which only one of the most recent will be mentioned here [54]. Fish reproduction must be closely adapted to the fluctuations of aquatic medium, whether such fluctuations result from cyclic seasonal variations or from migrations during the natural life cycle of some species. In those with seasonal reproduction, a major adaptation concerns spawning time which is adjusted in such a way that the specific food requirements of young fry coincide with the seasonal availability of that food. Depending on the species, this adjustment depends on specific characteristics of embryonic development duration, itself related to the amount of yolk and egg size. It involves an anticipation of the gametogenesis physiological processes, which can last more or less according to different species, from several months up to one year in some of them, such as salmonids. Most generally, as underlined by Bromage [54], the "photoperiod is the main factor entraining the endogenous processes or clocks which time reproduction, the other environmental factors probably acting in a permissive manner to 'gate' endogenous processes". Among these, temperature can obviously be expected to play an important role in poikilotherm species through modulation of all physiological processes and endocrine regulations. In some cases, temperature can simply play as a higher or lower limiting factor during certain gametogenesis stages. Thus meiotic maturation and ovulation in salmonids are inhibited over a higher threshold depending on species, of the order of $8^{\circ} \mathrm{C}$ in the Arctic charr Salvelinus alpinus [55], and of $15^{\circ} \mathrm{C}$ in rainbow trout [56]. Conversely, the same processes are reversibly blocked in the rainbow trout at excessively low temperatures [57]. However, the physiological targets of these inhibitions are not easy to dissociate, and endocrinological approaches often give paradoxical results. Thus, maintaining goldfish Carassius auratus at high water temperature after spawning also durably maintains a high plasma level of gonadotropin, but inhibits spermatogenesis [58]. Recent data obtained in the grass carp, Ctenopharyngodon idella, introduced in a tropical area, suggest that several relays along the brain-pituitarygonad axis may be simultaneously deregulated [59]. Apart from temperature, other physico-chemical factors can also play a 
role, especially in euryhaline migrating species, such as hydrostatic pressure associated with depth in the European anguilla Anguilla anguilla [60], water salinity changes in the Atlantic salmon Salmo salar, or water electric conductivity changes in mormyrids [61]. Finally, social factors, i.e. all congeneric signals, coming through visual, sound, tactile or chemical stimuli, may act more or less at some level in some species. They play a role in the control of sex differentiation in some hermaphroditic species, particularly in serranids, even in farmed species such as groupers [28, 62]. In the tilapia Oreochromis mossambicus, they advance the age at first spawning [63] or modulate the duration of the inter spawning interval [64]. But, most of all, social interactions are very important to synchronise maturation and release of gametes from both sexes during spawning. Thus, acoustic emissions in $O$. mossambicus was suggested to play a role in advertising the presence and spawning readiness of males and in synchronising gamete release [65]. Chemical signals appear generally as hormonal substances or their metabolites which are released into water and act as sex pheromones in addition to their hormonal role [66]. For example, 17,20 $\beta$-dihydroxy-4pregnen-3one and prostaglandin F2 $\alpha$ (PGF $2 \alpha$ ), two molecules that are respectively and successively involved in the control of oocyte maturation and ovulation in female goldfish, as will be seen below, are also released in water and trigger respectively and successively spermiation and spawning behaviour in the male [66]. In the African catfish Clarias gariepinus, steroid glucuronides released by the male act as olfactory stimulants promoting the attraction of ovulated females [67].

\subsection{Growth and reproduction}

A particularly original feature of most fish species compared to mammals is the absence of a definitive arrest of body growth in the adult. At the most, the growth curve may show some slowing down, more or less important according to species, related to the reproductive cycle [68]. As a result of this subcontinuous growth, absolute fecundity, i.e. the number of eggs produced by one female, is well known to increase in relation to female age and size. Besides, numerous fish species exhibit sex dimorphism, like many other vertebrates. Concerning farmed species, such a dimorphism leads to privileged rearing of the best growing sex, for example females in the sea-bass Dicentrarchus labrax [69] or males in the tilapia O. niloticus $[47,70]$. Moreover, growth difference in the latter species, is accentuated by female starvation during mouth brooding [71]. Finally, in some species like salmonids, the first spawning may occur one year earlier in males than in females. Since spawning is temporarily detrimental to body growth and flesh quality, this feature often leads to privileged female rearing, even in the absence of an important growth dimorphism [72].

All these interactions between growth and reproduction, also known to occur in many vertebrates, thus appear particularly important in fish. They are underlain by endocrine interactions between the gonadotropic axis and the somatotropic axis, among which the pituitary Growth Hormone appears to play a specific role in the physiology of puberty, gametogenesis and fertility [73].

\section{OOGENESIS}

\subsection{Ovary, ovarian follicle and oocyte}

Table II shows a brief survey of the diversity of egg characteristics in some species, related to the great variety of reproductive strategies. A much more exhaustive table can be consulted in the book of J. Mellinger [33].

Despite a great diversity in their aspect, the ovaries of numerous teleost species show a similar general structure that was already described some time ago [74]. In most cases, they generally appear as paired 
Table II. Egg number and size diversity in some teleost fish.

\begin{tabular}{lccl}
\hline Species & $\begin{array}{c}\text { Mean fecundity } \\
\left(\text { eggs number } \cdot \mathrm{kg}^{-1}\right)\end{array}$ & $\begin{array}{c}\text { Eggs mean diameter } \\
(\mathrm{mm})\end{array}$ & Particularities \\
\hline Turbot (Scophtalmus maximus) & 1000000 & 1.02 & Floating, pelagic \\
Cod (Gadus morhua) & 500000 & 1.4 & Floating, pelagic \\
Carp (Cyprinus carpio) & $50000-100000$ & $1-1.5$ & Adhesive on vegetal \\
& $2000-3000$ & $4-5.5$ & substrate \\
Salmonids & $50-200$ & $2-4$ & Benthic \\
Tilapia (genus Oreochromis) & $500-1000$ & $1-2$ & Substrate brooding \\
Tilapias (genus Tilapia) & & & \\
\hline
\end{tabular}

elongated organs oriented longitudinally within the abdominal cavity. They are surrounded by a conjunctive tunica, the mesovarium, adherent to the dorsal lining of the abdominal cavity, under the swim bladder. The posterior part of each ovary is prolonged by an oviduct connected to the genital papilla. Ovaries are compartmentalised by numerous septa formed by folds of the germinal epithelium, usually called ovigerous lamellae, projecting into the ovarian lumen. These lamellae contain nests of oogonia and oocytes at early stages of entry into the meiotic prophase, and follicles at various stages of oocyte and follicle growth and differentiation. In contrast to mammals, oogonia keep on proliferating in adult females [75] thus renewing the stocks of young oocytes and follicles. Oogonial mitosis may generally be observed more easily within the germinative epithelium after ovulation when the ovarian tissues are reorganising $[76,77]$ or in the remnant ovary just after unilateral ovariectomy [78]. At ovulation, mature oocytes are released from their follicle into the ovarian cavity, before being laid outside through the oviduct and the genital papilla. Apart from the schema above, there are some exceptions. Viviparous poecilids have only one ovary [79] which presents specialised structures devoted to long term preservation of spermatozoa $[52$, 53]. On the contrary, the ovaries of some species such as trout and salmon are not completely surrounded by the mesovarium and the ovigerous lamellae are open on the body cavity where mature oocytes are directly released at ovulation, and where they can remain some time before being laid though the genital papilla.

In comparison with a preovulatory mammalian follicle, a fish postvitellogenic follicle has no antrum, and most of its volume is occupied by the oocyte. At that stage the oocyte contains a great amount of yolk and a large germinal vesicle (several hundreds of microns), often localised in a peripheral position. It is surrounded by a relatively thick acellular envelope exhibiting a porous fibrillar structure [80], the zona radiata, and by several cell layers. A first monolayer of granulosa cells, directly attached to the zona radiata, is first surrounded by a thin basal lamina, and then by several more or less distinct theca cell layers. The zona radiata, which is the future egg shell or egg chorion, shows numerous tiny radial canals through which finger-like microvilli from the oocyte and from granulosa cells cross each other, linked by numerous "gap-junctions" [81, 82]. Granulosa cells form a regular monolayer, but the morphology and functions of these cells may be somewhat different between the animal and vegetal poles [83]. Moreover an enormous highly specialised cell at the animal pole, the micropylar cell, closes up the micropyle [84]. The last, which has been described in many species, appears as a kind of funnel with a small opening on the oocyte side of about $5 \mu$ in wide in the rainbow trout, which will be just enough to allow one sperm to get through 
[85]. Theca layers are vascularised by small capillary vessels, close to which special cells showing ultrastructural features of steroidogenic cells may be observed [86]. But granulosa cells are also known to participate in ovarian steroidogenesis by synthesising estradiol during vitellogenesis and progestins during oocyte maturation, from precursors provided by theca cells $[87,88]$. In rainbow trout, theca cells that were looking like fibroblast cells during vitellogenesis, undergo rapid morphological differentiation into smooth muscle-like cells during oocyte maturation and behave functionally as such [89]. Immediately after ovulation, these cells participate actively in the ovarian reorganisation, rapidly phagocytozing the collagen bundle, thus breaking down the pre-existent collagen fiber framework of the theca [90].

Oogenesis developmental stages have been extensively described in numerous species, with some differences depending on the species and the classification criteria. Only some of the earlier and the more minutely detailed will be mentioned here: in the flounder, Liopsetta obscura [91, 92], goldfish, Carassius auratus [93], several tilapia species [94], Fundulus heteroclitus [95], zebrafish Brachydanio rerio [96], and also reviews by Wallace and Selman [97] and Guraya [98]. Moreover, a recent review skimmed through the present state of knowledge about the mechanisms of oogenesis [99]. Therefore, only some original modalities compared to mammals will be developped below, concerning mainly vitellogenesis, oocyte meiotic maturation and ovulation.

\subsection{Vitellogenesis}

The storage in the oocyte of an important amount of yolk or vitellus, made of organic substances destined for embryo and larvae nutrition is an important original feature in all lower vertebrates. It generally requires an important metabolic effort for the maternal organism. Ovary weight can in fact reach 20 to $25 \%$ of body weight at the end of vitellogenesis, against about $1 \%$ some time after ovulation, in numerous species that spawn yearly only once, such as the rainbow trout. The term "vitellogenesis" has often been used to designate more or less restricted phases of a whole of complex processes, among which the synthesis of organic compounds within the oocyte, the incorporation of macromolecules synthesised in the liver and brought by the blood, and the deep reorganisation of all these reserves at the time of meiotic maturation [33]. This term will be used here in a restricted meaning, to designate only the accumulation of the lipoproteic yolk coming from its hepatic precursor, vitellogenin (vtg), brought by the blood. Vitellogenin is a glycolipophosphoprotein containing 79\% proteins and $19 \%$ lipids, with $70 \%$ phospholipids, in the rainbow trout [100]. It is synthesised in the liver in response to estrogenic stimulation [101-103], like most of zona radiata proteins (ZrP) in many species [104]. After leaving the blood vessels, vtg goes through the follicle wall and is selectively incorporated into the oocyte [105], by receptor-mediated endocytosis [106, 107]. $\mathrm{Vtg}$ is then transferred into multivesicular bodies from the lysosomial compartment [108] where it is colocalised with a proteolytic enzyme, cathepsin D [109], which is probably responsible for its cleavage into yolk proteins.

The duration of vitellogenesis is extremely variable depending on the species. It can be a lengthy process, from several months up to one year in species that spawn once a year with an important mass of large eggs, like salmonids. It lasts about 1-2 weeks in tilapias, tropical species that spawn several hundreds medium sized eggs every 3-4 weeks in favourable external conditions $[47,48]$. The duration of vitellogenesis can drop to about one day in medaka Oryzias latipes, spawning a few tens of small eggs every day [110].

Vitellogenesis regulation is overall under gonadotropic control by the pituitary. FSH (or GtH I) is expected to play the main role, 
as suggested by the endocrine and ovarian responses after unilateral ovariectomy [111], or the coincidence between FSH plasma levels and ovarian vitellogenic stages in the rainbow trout [112], even when vitellogenesis is accelerated through an accelerated photoperiodic regime [113]. The gonadotropic control is relayed in part by the ovarian production of estradiol [114], which is the main inductor of vitellogenin and $\mathrm{ZrP}$ synthesis in the liver. The respective roles of FSH and LH (or GtH II) in estradiol ovarian synthesis have been controversial for a long time, because both hormones are active to stimulate estradiol synthesis by ovarian follicles in vitro. However, recent data demonstrate a specific role of FSH when short incubation times are performed in vitro [115]. Such results would tend to confirm older data suggesting an increased efficiency of pulsatile gonadotropic action on ovarian estradiol production [116]. However, gonadotropic control by FSH also appears to act more or less directly upon vtg incorporation in the oocyte. First, estradiol which stimulates vtg synthesis by the liver, cannot stimulate vtg incorporation in the oocyte alone, as shown for example by the long term in vivo effect of estradiol silastic implants in the brook trout [117]. On the contrary, FSH appears to stimulate vtg incorporation into rainbow trout follicles in vitro [118]. However, other data in several other species suggest in fact that cooperation between various hormonal and paracrine factors are required to control vtg incorporation during vitellogenesis.

\subsection{Oocyte maturation and ovulation}

The term "oocyte maturation" designates a succession of complex cellular processes corresponding to meiosis resumption up to the second metaphase arrest in most vertebrates [119]. In fish, morphological manifestations of this phenomenon are more often easy to observe and have already been described some time ago throughout their progress in vivo [74]. A methodology based on in vitro experimentation and observa- tions, encouraged by professor Thibault, was developed thirty years ago [120-122], and was followed by numerous developments in France and in the world. Morphological features of maturation, more or les obvious depending on the species, are mainly the disparition (or "breakdown") of the germinal vesicle (GVBD), yolk clarification, and an increase of oocyte volume. GVBD, a phenomenon common to all vertebrates, corresponds to the first meiotic division immediately followed by the preparation of the second division that will remain blocked at metaphase II until fertilisation. Yolk clarification and oocyte volume increase are more particular to fish, but with some species differences. These phenomenon are due to a deep reorganisation of lipoproteic yolk [123-125] involving the action of proteolytic enzymes such as cathepsins [126]. In oocytes of marine fish that lay pelagic eggs, like the halibut Hippoglossus hippoglossus, this results in an important rise of free amino acids and ions, leading to an osmotic disequilibrium, thus causing water entry and multiplying oocyte volume by a factor of 4 [127]. Water entry is less important in marine fish laying demersal eggs, like Fundulus heteroclitus, just doubling oocyte volume [128], and does not go over $15 \%$ of oocyte volume in the rainbow trout (Jalabert et al. unpublished).

Ovulation is the release of a mature oocyte from its follicle into the ovarian cavity (or the abdominal cavity in salmonids). This process requires the separation of the oocyte from the granulosa layer, the rupture of follicle layers and the expulsion of the oocyte. Since the first data suggesting an implication of prostaglandin F2 as a possible local ovulation regulator in trout [89] and goldfish [129], a number of works [130] suggest that ovulation in fish probably involves the cooperation of various ovarian factors such as proteases and protease inhibitors, progestins, eicosanoids, catecholamines and vasoactive peptides, like in mammals [131]. 
Like in mammals, oocyte maturation and ovulation in fish are triggered by the action of pituitary gonadotropins on the surrounding follicle. This is why intrafollicular oocyte maturation of rainbow trout follicles has been used as a bioassay to prepare one of the first salmonid gonadotropins [132]. A typical "ovulatory discharge" of gonadotropin has been observed in some fish species such as the common carp Cyprinus carpio [133], but not in rainbow trout. Instead, in that species, plasma levels of both gonadotropins FSH and LH show a progressive moderate rise, starting respectively about 6 and 4 days (at $12{ }^{\circ} \mathrm{C}$ ) before the beginning of maturation [112]. Moreover, a second rise of plasma gonadotropins, in a much larger range than the first increase, was observed after ovulation, but depending on the evacuation or retention of ovulated eggs: taking these immediately after ovulation promoted a large increase of FSH levels and a decrease of LH during two weeks after ovulation, whereas the retention of eggs in the body cavity promoted a large increase of $\mathrm{LH}$ and only a weak increase of FSH during the same time. These differences in both gonadotropin postovulatory profiles may be suggested to be related either to postovulatory ovarian reorganisation, including gonial multiplications, and/or to the preservation of the quality of ovulated eggs when these are retained a long time in the body cavity. In any case, it seems obvious that both gonadotropins are actually involved in the endocrine regulation of follicular events just preceding, accompanying and following maturation and ovulation.

In contrast to mammals, but like in amphibians, the gonadotropic action which triggers oocyte maturation in fish is clearly relayed by a steroid hormone, designated by the term "maturation inducing hormone" or MIS, synthesised by the follicular envelopes [119]. In salmonids and some other freshwater fish, the MIS is a progestin, 17,20 $\beta$ dihydroxy-4pregnen-3one or DHP, which was first identified in the plasma of Pacific salmon (Oncorhynchus nerka) during the periovulatory period. Its predominant effi- ciency to trigger oocyte maturation was first demonstrated in vitro in rainbow trout [134]. Then, it was identified in the incubation medium of follicles from another salmonid, stimulated by a salmon gonadotropin [135]. In various marine species, such as the spotted sea-trout Cynoscion nebulosus, another progestin, 17,20ß,21-trihydroxy4pregnen-3one, has been identified as a MIS [136]. Moreover, two different MIS receptors have been identified in this species, a membrane receptor [137], and a nuclear receptor [138], exhibiting very different binding affinities for various C21 steroids [139]. The membrane receptor would be more particularly responsible for the non genomic action of the MIS on oocyte maturation, whereas the nuclear receptor would be responsible for a genomic action promoting ovulation [140]. The gene of the membrane receptor, which was recently cloned [141], seems to belong to a family, so far unknown, of putative membrane receptor genes that is present in various vertebrates, including humans, Xenopus, Fugu, and zebrafish [142]. Details about the follicular mechanisms triggered by nuclear receptor activation are almost unknown. On the contrary, many works have been devoted in the world to mechanisms triggered in the oocytes of amphibians, mammals and fish, by the non-genomic activation of a putative membrane receptor. These results will not be developed here since they have been extensively reviewed and because they tend to emerge into a general model [143].

Follicular and oocyte competence are defined as the ability to respond correctly to a hormonal stimulation by producing good quality oocytes, i.e. able to develop normally after fertilisation. Like in mammals, the acquisition of follicular and oocyte competence is a crucial problem, because fish farming constraints often require artificially controlling the end of the reproductive cycle, and imposing quality norms concerning the results. Several factors have been involved in the control of competence acquisition, particularly the state of homologous 
and heterologous gap-junctions, connexins, IGF and activins [99]. In rainbow trout ovaries, the analysis of expression profiles of various genes during the preovulatory period allows to associate the evolution of some of them with competence acquisition [144-146]. Most correspond to factors which have already be suggested, in other teleost or in mammals, to be involved in competence acquisition, in modulation of follicular or oocyte sensitivity to hormones, in yolk processing, or in ovulation mechanisms. This is the case of IGF 1 and 2, FSH receptors, members of the activin and inhibin family, cathepsins, and enzymes of the prostaglandin biosynthesis pathway. The multiplicity of factors putatively involved is not surprising, since competence acquisition necessarily corresponds in fact to the progressive coordinate differentiation of several ovarian compartments. Moreover, if the necessity of some physiological coordination between the acquisition of follicular competence as a whole, and the emission of appropriate stimulating signals from the neuroendocrine system seems obvious, insufficient attention has probably been paid so far to signals from the ovaries, and not only steroids. Finally, the analysis of gonadotropic signals from the pituitary should not be limited to the mean absolute level of FSH and $\mathrm{LH}$, but should also take into account short-term profiles, thus renewing ancient works performed when available assays probably only gave a mean value between both gonadotropins [147].

\section{APPLICATIONS}

Research carried out in the world during the last thirty years on reproductive mechanisms in the teleost has certainly increased our knowledge concerning not only fish, but also vertebrates as a whole. The contribution to a general model of cellular mechanisms of meiotic maturation [143], or the possible discovery of a gene family of putative steroid membrane receptors present in various vertebrates and humans [142] are only stimulating examples of possible generalisations. New knowledge has opened on applications not only in the field of fish farming but also in the field of environmental evaluation. Taking into account the importance of permanent exchanges with their aquatic environment, fish appear as sensitive indicators of the quality of this environment which is a receptacle of many substances coming from human activities [148]. Thus, the sensitivity of the hepatic responses to estrogen-like pollutants, and the relative simplicity of $\mathrm{vtg}$ and $\mathrm{ZrP}$ detection in vivo in the blood or in vitro in hepatic cell cultures [149], has incited a considerable number of works in the world to use these responses as biomarkers of exposition [150], or to evaluate estrogen-like potency of various substances [151]. But many other important reproductive mechanisms can be negatively affected by xenobiotics, like simple morphological features such as the gonopodium of the mosquito fish [151], or more complex phenomenon such as in vitro oocyte maturation [152].

In the field of fish culture, only some applications, which result from fish reproductive particularities compared to mammals, will be mentioned here. Thus, the external character of fertilisation has favoured various kinds of manipulations on both gametes, such as sperm irradiation to inactivate the genome without altering its motility and its ability to activate the oocyte, and the application of thermic or hyperbare shocks to the eggs in order to inhibit either the second meiotic division (retention of the first polar body), or the first embryo mitosis, depending on the chronology of these shocks during and after fertilisation events. These manipulations theoretically allow obtaining several kinds of chromosome stock modifications (Fig. 1) [153]. One of the most interesting modifications for fish farming is triploidy which can give sterile fish that are expected not to waste energy for gonadal growth instead of body growth. In salmonids, the first positive results were obtained by using thermic shocks [154], 


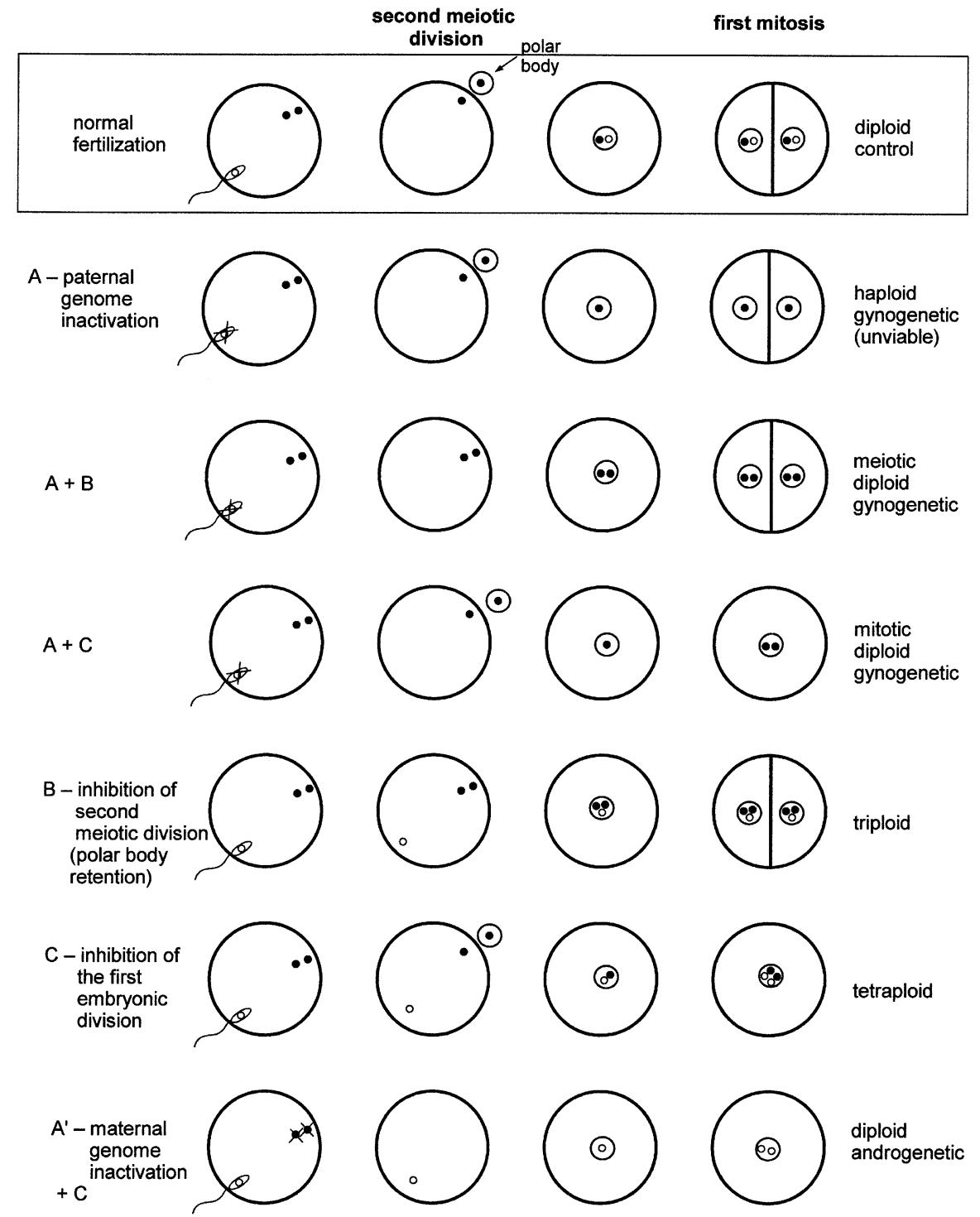

Figure 1. Theoretical possibilities of intervention on fertilisation in fish: destruction of paternal genome (A); inhibition of 2 nd meiotic division through retention of the second polar body (B); blockage of first embryo mitosis (C). A selected combination among these possibilities allows obtaining original genetic products (gynogenetic, androgenetic, triploid, tetraploid) (after Breton et al. [154]). 
then hyperbare shocks [155], that are now widely used in industrial practice.

Similarly, the external character of embryonic and larval development is highly favourable to the application of various chemical treatments. This is especially the case of all treatments administrated either through balneation or via the food of young fry, in order to obtain phenotypic sex inversion in the trout [72], tilapias [47], and presently many other species. In the rainbow trout, androgen treatments are able to produce $\mathrm{XX}$ neomales that are used as brooders to inseminate eggs of normal XX females, thus giving monosex female populations that have never been directly treated by steroids. Moreover, insemination may be combined with thermic or hyperbare treatments, to obtain, through second polar body retention, triploid sterile monosex female populations, that can be used to rear large fish in which growth will not be slowed down by reproduction [153]. Finally, in tilapias, where male monosex populations are preferred for farming, these can be obtained by crossing normal females with "neo-super males" of genotype YY. These, which are viable and functional, are obtained by crossing normal XY males with neo XY females resulting from estrogenic treatment of normal fry [156].

The practical use in fish of artificial photoperiods to control the spawning season [157], and of hormonal treatments to induce maturation and ovulation [153] are mentioned here only as a matter of interest and will not be developed.

\section{REFERENCES}

[1] Wooton RJ. Introduction: tactics and strategies in fish reproduction. In: Poots GW, Wootton RJ (Eds), Fish Reproduction: Strategies and tactics, Academic Press, London, 1984, p 1-12.

[2] Powers DA. Fish as Model Systems. Science 1989, 246: 352-358.

[3] Devlin RH, Nagahama Y. Sex determination and sex differentiation in fish: an overview of genetic, physiological, and environmental influences. Aquaculture 2002, 208: 191-364.

[4] Yamamoto T. Sex differentiation. In: Hoar WS, Randall DJ (Eds), Fish Physiology, Academic Press, New York, 1969, Vol3, p 117-175.

[5] Baroiller JF, Guigen Y, Fostier A. Endocrine and environmental aspects of sex differentiation in fish. Cell Mol Life Sci 1999, 55: 910931.

[6] Nakayama I, Foresti F, Tewari R, Schartl M, Chourrout D. Sex chromosome polymorphism and heterogametic males revealed by two cloned DNA probes in the ZW/ZZ fish Leporinus elongatus. Chromosoma 1994, 103: 31-39.

[7] Chourrout D. Revue sur le déterminisme génétique du sexe chez les poissons téléostéens. Bull Soc Zool Fr 1988, 113: 123 144.

[8] Clemens HP, Inslee T. The Production of Unisexual Broods by Tilapia mossambica Sexreversed with Methyl Testosterone. Trans Amer Fish Soc 1968, 97: 18-21.

[9] Jalabert B, Moreau J, Planquette P, Billard R. Déterminisme du sexe chez Tilapia macrochir et Tilapia nilotica: action de la methyltestostérone dans l'alimentation des alevins sur la différenciation sexuelle ; obtention de mâles inversés fonctionnels et proportion des sexes dans la descendance. Ann Biol Anim Biochim Biophys 1974, 14: 729-739.

[10] Chourrout D, Quillet E. Induced gynogenesis in the rainbow trout: sex and survival of progenies of all-triploid populations. Theor Appl Genet 1982, 63: 201-205.

[11] Jalabert B, Kammacher P, Lessent P. Déterminisme du sexe chez les hybrides entre Tilapia macrochir et Tilapia nilotica. Étude de la sex-ratio dans les recroisements des hybrides par les espèces parentes. Ann Biol Anim Biochim Biophys 1971, 11: 155-165.

[12] Harvey S, Masabanda J, Carrasco L, Bromage N, Penman D, Griffin D. Molecular-cytogenetic analysis reveals sequence differences between the sex chromosomes of Oreochromis niloticus: evidence for an early stage of sex-chromosome differentiation. Cytogenet Genome Res 2002, 97: 76-80.

[13] Harvey S, Boonphakdee C, Campos-Ramos R, Ezaz M, Griffin D, Bromage N, Penman D. Analysis of repetitive DNA sequences in the sex chromosomes of Oreochromis niloticus. Cytogenet Genome Res 2003, 101: 314-319.

[14] Ezaz M, Myers J, Powell S, McAndrew B, Penman D. Sex ratios in the progeny of androgenetic and gynogenetic YY male Nile tilapia, Oreochromis niloticus L. Aquaculture 2004, 232: 205-214. 
[15] Woram R, Gharbi K, Sakamoto T, Hoyheim B, Holm L, Naish K, McGowan C, Ferguson M, Phillips R, Stein J, Guyomard R, Cairney M, Taggart J, Powell R, Davidson W, Danzmann $\mathrm{R}$. Comparative genome analysis of the primary sex-determining locus in salmonid fishes. Genome Res 2003, 13: 272-280.

[16] Quillet E, Aubard G, Queau I. Mutation in a sex-determining gene in rainbow trout: detection and genetic analysis. J Hered 2002, 93: 91-99.

[17] Chevassus B, Devaux A, Chourrout D, Jalabert B. Production of YY rainbow trout males by self-fertilization of induced hermaphrodites. J Hered 1988, 79: 89-92.

[18] Hostache G, Pascal M, Tessier C. Influence of the incubation-temperature on the malefemale ratio of atipa Eggs, Hoplosternum littorale Hancock (1828). Can J Zool 1995, 73: 1239-1246.

[19] Baroiller J, Chourrout D, Fostier A, Jalabert B. Temperature and sex chromosomes govern sex ratios of the mouthbrooding cichlid fish Oreochromis niloticus. J Exp Zool 1995, 273: 216-223.

[20] Pavlidis M, Koumoundouros G, Sterioti A, Somarakis S, Divanach P, Kentouri M. Evidence of temperature-dependent sex determination in the European sea bass (Dicentrarchus labrax L.). J Exp Zool 2000, 287: 225232.

[21] Saillant E, Fostier A, Haffray P, Menu B, Thimonier J, Chatain B. Temperature effects and genotype-temperature interactions on sex determination in the European sea bass (Dicentrarchus labrax L.). J Exp Zool 2002, 292: 494-505.

[22] Saillant E, Fostier A, Haffray P, Menu B, Chatain B. Saline preferendum for the European sea bass, Dicentrarchus labrax, larvae and juveniles: effect of salinity on early development and sex determination. J Exp Mar Biol Ecol 2003, 287: 103-117.

[23] Donaldson E. Manipulation of reproduction in farmed fish. Anim Reprod Sci 1996, 42: 381392.

[24] Reinboth R. Intersexuality in fishes. Mem Soc Endocrinol 1970, 18: 515-543.

[25] Guiguen Y, Cauty C, Fostier A, Fuchs J, Jalabert B. Reproductive cycle and sex inversion of the seabass, Lates calcarifer, reared in sea cages in French Polynesia: histological and morphometric description. Environ Biol Fish 1994, 39: 231-247.

[26] Zohar Y, Abraham M, Gordin H. The gonadal cycle of the captivity-reared hermaphroditic teleost Sparus aurata (L.) during the first two years of life. Ann Biol Anim Biochim Biophys 1978, 18: 877-882.

[27] Fostier A, Kokokiris L, Menn F, Mourot B, Pavlidis M, Divanach P, Kentouri M. Recent advances in reproductional aspects of Pagrus pagrus. Cahiers Options Mediterraneennes 2000, 47: 181-192.

[28] Debas L, Fostier A, Fuchs J, Weppe M, Nedelec G, Bennett A, Aquacop, Cauty C, Jalabert B. The sexuality of cultured hermaproditic fish species: analysis of morphological and endocrine features in a protogynous hermaphrodite, Epinephelus microdon, as a basis to control reproduction in the groupe. In: IFREMER (Ed), Advances in tropical Aquaculture, Tahiti, French Polynesia, 1989, p 543-557.

[29] Fischer EA. The relationship between mating system and simultaneous hermaphroditism in the coral reef fish, Hypoplectrus nigricans (Serranidae). Anim Behav 1980, 28: 620-633.

[30] Harrington RW. Oviparous hermaphroditic fish with internal self-fertilization. Science 1961, 134 (3492): 1749-1750.

[31] Harrington RW. Environmentally controlled induction of primary male gonochorists from eggs of the self-fertilizing hermaphroditic fish, Rivulus marmoratus Poey. Biol Bull 1967, 132: 174-199.

[32] Weibel AC, Dowling TE, Turner BJ. Evidence that an outcrossing population is a derived lineage in a hermaphroditic fish (Rivulus marmoratus). Evolution 1999, 53: 1217 1225.

[33] Mellinger J. Sexualité et Reproduction des Poissons. CNRS editions, Paris, 2002.

[34] Chevassus B. Modification du phénotype sexuel et du mode de reproduction chez les poissons salmonidés : inversion sexuelle hormonale, gynogenèse, hybridation interspécifique et polyploïdisation. Thèse doctorat Univ Paris Sud, 1998.

[35] Hubbs CL, Hubbs LC. Apparent parthenogenesis in nature, in a form of fish of hybrid origin. Science 1932, 76: 628-630.

[36] Kallman KD. Population genetics of the gynogenetic teleost, Mollienesia formosa (Girard). Evolution 1962, 16: 497-504.

[37] Rasch EM, Monaco PJ, Balsano JS. Cytophotometric and autoradiographic evidence for functional apomixis in a gynogenetic fish, Poecilia formosa and its related, triploid unisexuals. Histochemistry 1982, 73: 515-533.

[38] Schartl M, Wilde B, Schlupp I, Parzefall J. Evolutionary origin of a parthenoform, the Amazon molly, P. formosa, on the basis of a 
molecular genealogy. Evolution 1995, 49: 827-835.

[39] Yamashita M, Jiang J, Onozato H, Nakanishi T, Nagahama Y. A Tripolar Spindle Formed at Meiosis I Assures the Retention of the Original Ploidy in the Gynogenetic Triploid Crucian Carp, Ginbuna Carassius Auratus Langsdorfii. Dev Growth Differ 1993, 35: 631-636.

[40] Yamashita M, Onozato H, Nakanishi T, Nagahama Y. Breakdown of the sperm nuclear envelope is a prerequisite for male pronucleus formation: direct evidence from the gynogenetic crucian carp, Carassius auratus langsdorfii. Develop Biol 1990, 137: 155160.

[41] Schultz RJ. Hybridization, unisexuality, and polyploidy in the teleost Peciliopsis (Peciliidae) and other vertebrates. Am Nat 1969, 103: 605-619.

[42] Xie J, Wen JJ, Chen B, Gui JF. Differential gene expression in fully-grown oocytes between gynogenetic and gonochoristic crucian carps. Gene 2001, 271: 109-116.

[43] Marteinsdottir G, Gudmundsdottir A, Thorsteinsson V, Stefansson G. Spatial variation in abundance, size composition and viable egg production of spawning cod (Gadus morhua L.) in Icelandic waters. Ices J Mar Sci 2000, 57: 824-830.

[44] Linhart O, Kudo S, Billard R, Slechta V, Mikodina EV. Morphology, composition and fertilization of carp eggs: a review. Aquaculture 1995, 129: 75-93.

[45] Legendre M, Linhart O, Billard R. Spawning and management of gametes, fertilized eggs and embryos in Siluroidei. Aquat Living Resour 1996, 9: 59-80.

[46] Hostache G, Mol JH. Reproductive biology of the neotropical armoured catfish Hoplosternum littorale (Siluriformes, Callichthyidae): a synthesis stressing the role of the floating bubble nest. Aquat Living Resour 1998, 11: 173185.

[47] Baroiller J-F, Jalabert B. Contribution of research in reproductive physiology to the culture of tilapias. Aquat Living Resour 1989, 2: 105-116.

[48] Tacon P, Ndiaye P, Cauty C, Menn F, Jalabert B. Relationships between the expression of maternal behaviour and ovarian development in the mouthbrooding cichlid fish Oreochromis niloticus. Aquaculture 1996, 146: 261-275.

[49] Tacon P, Baroiller JF, Le Bail PY, Prunet P, Jalabert B. Effect of egg deprivation on sex steroids, gonadotropin, prolactin, and growth hormone profiles during the reproductive cycle of the mouthbrooding cichlid fish Oreochromis niloticus. Gen Comp Endocrinol 2000, 117: 54-65.

[50] Fishelson L, Hilzerman F. Flexibility in reproductive styles of male St. Peter's tilapia, Sarotherodon galilaeus (Cichlidae). Environ Biol Fish 2002, 63: 173-182.

[51] Rosen DE, Gordon M. Functional anatomy and evolution of male genitalia in Poecilid Fishes. Zoologica 1953, 38: 1-47.

[52] Jalabert B, Billard R. Étude ultrastructurale du site de conservation des spermatozoides dans l'ovaire de Poecilia reticulata (Poisson téléostéen). Ann Biol Anim Biochim Biophys 1969, 9: 273-280.

[53] Kobayashi H, Iwamatsu T. Fine structure of the storage micropocket of spermatozoa in the ovary of the guppy Poecilia reticulata. Zool Sci 2002, 19: 545-555.

[54] Bromage N, Porter M, Randall C. The environmental regulation of maturation in farmed finfish with special reference to the role of photoperiod and melatonin. Aquaculture 2001, 197: 63-98.

[55] Gillet C. Egg production in an Arctic charr (Salvelinus alpinus L.) brood stock: effects of temperature on the timing of spawning and the quality of eggs. Aquat Living Resour 1991, 4: 109-116.

[56] Pankhurst N, Purser G, Kraak G, Thomas P, Forteath G. Effect of holding temperature on ovulation, egg fertility, plasma levels of reproductive hormones and in vitro ovarian steroidogenesis in the rainbow trout Oncorhynchus mykiss. Aquaculture 1996, 146: 277 290.

[57] Morrison JK, Smith CE. Altering the spawning cycle of rainbow trout by manipulating water temperature. Prog Fish-Cult 1986, 5254.

[58] Gillet C, Billard R, Breton B. Effets de la température sur le niveau de gonadotropine plasmatique et la spermatogenèse chez le poisson rouge, Carassius auratus. Can J Zool 1977, 55: 242-245.

[59] Glasser F, Mikolajczyk T, Jalabert B, Baroiller JF, Breton B. Temperature effects along the reproductive axis during spawning induction of grass carp (Ctenopharyngodon idella). Gen Comp Endocrinol 2004, 136: 171-179.

[60] Dufour S. The Neuroendocrinology of Eel Reproduction - from Fundamental Research to Applied Problems. Bull Fr Peche Piscic 1994, 187-211.

[61] Schugardt C, Kirschbaum F. Control of gonadal maturation and regression by experimental variation of environmental factors in 
the mormyrid fish, Mormyrus rume proboscirostris. Environ Biol Fish 2004, 70: 227-233.

[62] Quinitio GF, Caberoy NB, Reyes DM. Induction of sex change in female Epinephelus coioides by social control. Isr $\mathrm{J}$ AquacultBamidgeh 1997, 49: 77-83.

[63] Silvermann H. The effects of visual social stimulation upon age at first spawning in the mouth-brooding cichlid fish Sarotherodon (Tilapia) mossambicus (Peters). Anim Behav 1978, 26: 1120-1125.

[64] Silvermann H. Effects of different levels of sensory contact upon reproductive activity of adult male and female Sarotherodon (tilapia) mossambicus. Anim Behav 1978, 26: 10811090.

[65] Amorim MCP, Fonseca PJ, Almada VC. Sound production during courtship and spawning of Oreochromis mossambicus: male-female and male-male interactions. J Fish Biol 2003, 62: 658-672.

[66] Kobayashi M, Sorensen PW, Stacey NE. Hormonal and pheromonal control of spawning behavior in the goldfish. Fish Physiol Biochem 2002, 26: 71-84.

[67] Hurk R, Resink J. Male reproductive system as sex pheromone producer in teleost fish. $\mathrm{J}$ Exp Zool 1992, 261: 204-213.

[68] Le Bail PY. Growth-reproduction interaction in salmonids. In: Zohar Y, Breton B (Eds), Reproduction in fish, basic and applied aspects in endocrinology and genetics, INRA éditions, Paris, Les colloques de l'INRA, $\mathrm{N}^{\circ} 44,1988$, p 91-108.

[69] Saillant E, Fostier A, Menu B, Haffray P, Chatain B. Sexual growth dimorphism in sea bass Dicentrarchus labrax. Aquaculture 2001, 202: 371-387.

[70] Toguyeni A, Fauconneau B, Fostier A, Abucay J, Mair G, Baroiller JF. Influence of sexual phenotype and genotype, and sex ratio on growth performances in tilapia, Oreochromis niloticus. Aquaculture 2002, 207: 249-261.

[71] Massou AM, Panfili J, Le Bail PY, Lae R, Mikolasek O, Fontenelle G, Baroiller JF. Evidence of perturbations induced by reproduction on somatic growth and microincrement deposition in Orochromis niloticus otoliths. J Fish Biol 2004, 64: 380-398.

[72] Chevassus B, Chourrout D, Jalabert B. Le contrôle de la reproduction chez les poissons. 1. Les populations "monosexes". Bull Fr Piscic 1979, No. 274: 18-31.

[73] Legac F, Blaise O, Fostier A, Lebail PY, Loir M, Mourot B, Weil C. Growth-Hormone (Gh) and Reproduction - A Review. Fish Physiol Biochem 1993, 11: 219-232.
[74] Fulton TW. On the growth and maturation of the ovarian eggs ofteleostean fishes. In: 16th Annual Report of the Fishery Board for Scotland, Part III, 1898, p 88-124.

[75] Tokarz RR. Oogonial proliferation, oogenesis and folliculogenesis in nonmammalian vertebrates. In: Jones RE (Ed), The vertebrate ovary. Comparative Biology and evolution, Plenum Press, New York, 1978, p 145-179.

[76] Billard R. The reproductive cycle of male and female brown trout (Salmo trutta fario): a quantitative study. Reprod Nutr Dev 1987, 27 : 29-44.

[77] Sriramulu V, Rajalakshmi M. Origin of a new crop of oocytes in Gobius giuris (HamiltonBuchanan). Z Mikrosk Anat Forsch 1966, 75: 63-73.

[78] Dadzie S, Hyder M. Compensatory hypertrophy of the remaining ovary and the effect of methallibure in the unilaterally ovariectomized Tilapia aurea. Gen Comp Endocrinol 1976, 29: 433-440.

[79] Chambolle P. Recherches sur les facteurs physiologiques de la reproduction chez les poissons "ovovivipares". Analyse expérimentale sur Gambusia sp. Bull Biol 1973, 107: 29101.

[80] Flugel H. Licht- und elektronenmikroskopische Untersuchungen an Oozyten und Eiern einiger Knochenfische. Z Zellforsch Mikrosk Anat 1967, 83: 82-116.

[81] Kessel RG, Tung HN, Roberts R, Beams HW. The presence and distribution of gap junctions in the oocyte-follicle cell complex of the zebrafish, Brachydanio rerio. J Submicrosc Cytol 1985, 17: 239-253.

[82] Toshimori K, Yasuzumi F. Gap Junctions between Microvilli of an Oocyte and Follicle Cells in the Teleost (Plecoglossis altivelis). Z Mikrosk Anat Forsch 1979, 93: 458-464.

[83] Iwamatsu T, NakashimaS, Onitake K, Matsuhisa A, Nagahama Y. Regional Differences in Granulosa-Cells of Preovulatory Medaka Follicles. Zool Sci 1994, 11: 77-82.

[84] Riehl R, Götting KJ. Zur Struktur und Vorkommen de Mikropyle an Eizellen und Eiern von Knochenfischen (Teleostei). Arch Hydrobiol 1974, 74: 393-402.

[85] Szöllösi D, Billard R. The micropyle of trout eggs and its reaction to different incubation media. J Microsc 1974, 21: 55-62.

[86] Nagahama Y. The functional morphology of teleost gonads. In: Hoar WS, Randall DJ (Eds), Fish physiology, Vol IX, Reproduction Part A, Endocrine tissues and hormones, Academic Press, New York, USA, 1983, p 223 275. 
[87] Nagahama Y. Gonadotropin action on gametogenesis and steroidogenesis in teleost gonads. Zool Sci 1987, 4: 209-222.

[88] Senthilkumaran B, Yoshikuni M, Nagahama Y. A shift in steroidogenesis occurring in ovarian follicles prior to oocyte maturation. Mol Cell Endocrinol 2004, 215: 11-18.

[89] Jalabert B, Szöllösi D. In vitro ovulation of trout oocytes: effect of prostaglandins on smooth muscle-like cells of the theca. Prostaglandins 1975, 9: 765-778.

[90] Szöllösi D, Jalabert B, Breton B. Postovulatory changes in the theca folliculi of the trout. Ann Biol Anim Biochim Biophys 1978, 18: 883-891.

[91] Yamamoto KI. Annual cycle in the development of ovarian eggs in the flounder, Liopsetta obscura. J Fac Sci Hokkaido Univ, Ser VI (Zool) 1956, 12: 362-373.

[92] Yamamoto K. II. Changes in the nucleus of the oocyte of Liopsetta obscura, with special reference to the activity of the nucleolus. $J$ Fac Sci Hokkaido Univ, Ser VI (Zool) 1956, 12: 375-390.

[93] Yamamoto K, Yamazaki F. Rhythm of development in the oocyte of the gold-fish, Carassius auratus. Bull Fac Fish Hokkaido Univ 1961, 12: 93-110.

[94] Kraft AV, Peters HM. Vergleichende Studien über die Oogenese in der Gattung Tilapia (Cichlidae, Teleostei). ZZellforsch 1963,61: 434-485.

[95] Selman K, Wallace R. Gametogenesis in Fundulus heteroclitus. Am Zool 2005, 26: 173-192.

[96] Selman K, Wallace R, Sarka A, Qi X. Stages of oocyte development in the zebrafish, Brachydanio rerio. J Morphol 1993, 218: 203-224.

[97] Wallace R, Selman K. Cellular and dynamic aspects of oocyte growth in teleosts. Am Zool 1981, 21: 325-343.

[98] Guraya SS. The Cell and Molecular Biology of Fish Oogenesis. Monographs in Developmental Biology, Sauer HW (Ed), Karger, Basel, München, Paris, London, New York, New Delhi, Singapore, Tokyo, Sydney 1986, 18: 1-223.

[99] Patino R, Sullivan CV. Ovarian follicle growth, maturation, and ovulation in teleost fish. Fish Physiol Biochem 2002, 26: 57-70.

[100] Frémont L, Riazi A. Biochemical analysis of vitellogenin from rainbow trout (Salmo gairdneri): Fatty acid composition of phospholipids. Reprod Nutr Dev 1988, 28: 939 952.
[101] Bohemen CG, Lambert JGD, Peute J. Annual changes in plasma and liver in relation to vitellogenesis in the female rainbow trout, Salmo gairdneri. Gen Comp Endocrinol 1981, 44: 94-107.

[102] Vaillant C, Le Guellec C, Pakdel F, Valotaire $\mathrm{Y}$. Vitellogenin gene expression in primary culture of male rainbow trout hepatocytes. Gen Comp Endocrinol 1988, 70: 284-290.

[103] Emmersen BK, Petersen IM. Natural occurrence, and experimental induction by estradiol-17-beta, of a lipophosphoprotein (vitellogenin) in flounder (Platichtys flesus, L.). Comp Biochem Physiol B 1976, 54: 443446.

[104] Hyllner SJ, Oppen-Berntsen DO, Helvik JV, Walther BT, Haux C. Oestradiol-17 beta induces the major vitelline envelope proteins in both sexes in teleosts. J Endocrinol 1991, 131: 229-236.

[105] Campbell CM, Jalabert B. Selective protein incorporation by vitellogenic Salmo gairdneri oocytes in vitro. Ann Biol Anim Biochim Biophys 1979, 19: 429-437.

[106] Nunez-Rodriguez J, Bon E, Menn FL. Vitellogenin receptors during vitellogenesis in the rainbow trout Oncorhynchus mykiss. J Exp Zool 1996, 274: 163-170.

[107] Avail B, Pakdel F, Bujo H, Perazzolo LM, Waclawek M, Schneider WJ, Menn Fl. Evolution of oogenesis: the receptor for vitellogenin from the rainbow trout. J Lipid Res 1998, 39: 1929-1937.

[108] Busson-Mabillot S. Endosomes transfer yolk proteins to lysosomes in the vitellogenic oocyte of the trout. Biol Cell 1984, 51:53-66.

[109] Sire MF, Babin PJ, Vernier JM. Involvement of the Lysosomal System in Yolk Protein Deposit and Degradation During Vitellogenesis and Embryonic-Development in Trout. J Exp Zool 1994, 269: 69-83.

[110] Iwamatsu T, Ohta T, Oshima E, Sakai N. Oogenesis in the medaka Oryzias latipes stages of oocyte development. Zool Sci 1988, 5: 353-373.

[111] Tyler CR, Pottinger TC, Coward K, Prat F, Beresford N, Maddix S. Salmonid folliclestimulating hormone $(\mathrm{GtH}$ I) mediates vitellogenic development of oocytes in the rainbow trout, Oncorhynchus mykiss. Biol Reprod 1997, 57: 1238-1244.

[112] Breton B, Govoroun M, Mikolajczyk T. GTH I and GTH II secretion profiles during the reproductive cycle in female rainbow trout: relationship with pituitary responsiveness to GnRH-A stimulation. Gen Comp Endocrinol 1998, 111: 38-50. 
[113] Bon E, Breton B, Govoroun M, Menn F. Effects of accelerated photoperiod regimes on the reproductive cycle of the female rainbow trout: II seasonal variations of plasma gonadotropins (GTH I and GTH II) levels correlated with ovarian follicle growth and egg size. Fish Physiol Biochem 1999, 20: 143-154.

[114] Idler DR, Campbell CM. Gonadotropin stimulation of estrogen and yolk precursor synthesis in juvenile rainbow trout. Gen Comp Endocrinol 1980, 41: 384-391.

[115] Montserrat N, Gonzalez A, Mendez E, Piferrer F, Planas JV. Effects of follicle stimulating hormone on estradiol-17 beta production and P-450 aromatase (CYP19) activity and mRNA expression in brown trout vitellogenic ovarian follicles in vitro. Gen Comp Endocrinol 2004, 137: 123-131.

[116] Zohar Y, Breton B, Fostier A. Gonadotropic function during the reproductive cycle of the female rainbow trout, Salmo gairdneri, in relation to ovarian steroid secretion: in vivo and in vitro studies. In: Richter CJJ, Goos HJT (Eds), Reproductive Physiology of Fish, PUDOC, Wageningen, 1982, p 14-18.

[117] Lessman C, Habibi H. Estradiol-17 beta Silastic implants suppress oocyte development in the brook trout, Salvelinus fontinalis. Gen Comp Endocrinol 1987, 67: 311-323.

[118] Tyler CR, Sumpter JP, Kawauchi H, Swanson $\mathrm{P}$. Involvement of gonadotropin in the uptake of vitellogenin into vitellogenic oocytes of the rainbow trout, Oncorhynchus mykiss. Gen Comp Endocrinol 1991, 84: 291-299.

[119] Jalabert B, Fostier A, Breton B, Weil C. Oocyte maturation in vertebrates. In: Pang PKT, Schreibman MP (Eds), Vertebrate endocrinology: fundamentals and biomedical implications, Vol 4, Part A, Academic Press, 1991, p 23-90.

[120] Jalabert B, Breton B, Bry C. Maturation et ovulation in vitro des ovocytes de la truite arc-en-ciel Salmo gairdnerii. C R Acad Sci Hebd Seances Acad Sci D 1972, 275: 1139 1142.

[121] Jalabert B. In vitro oocyte maturation and ovulation in rainbow trout (Salmo gairdneri), northern pike (Esox lucius), and goldfish (Carassius auratus). J Fish Res Board Can 1976, 33: 974-988.

[122] Jalabert B. Production of fertilizable oocytes from follicles of rainbow trout (Salmo gairdneri) following in vitro maturation and ovulation. Ann Biol Anim Biochim Biophys 1978, 18: 461-470.
[123] Carnevali O, Mosconi G, Roncarati A, Bervedere P, Romano M, Limatola E. Changes in the electrophoretic pattern of the yolk proteins during vitellogenesis in the gilthead sea bream Sparus aurata L. Comp Biochem Physiol B 1992, 103: 955-962.

[124] Iwamatsu T, Takahashi SY, Ohishi M, Yokochi T, Maeda H. Changes in Electrophoretic Patterns of Oocyte Proteins During Oocyte Maturation in Oryzias latipes. Develop Growth Differ 1992, 34: 173-179.

[125] Matsubara T, Sawano K. Proteolytic cleavage of vitellogenin and yolk proteins during vitellogenin uptake and oocyte maturation in barfin flounder (Verasper moseri). J Exp Zool 1995, 272: 34-45.

[126] Carnevali O, Carletta R, Cambi A, Vita A, Bromage N. Yolk formation and degradation during oocyte maturation in seabream Sparus aurata: Involvement of two lysosomal proteinases. Biol Reprod 1999, 60: 140-146.

[127] Finn RN, Ostby GC, Norberg B, Fyhn HJ. In vivo oocyte hydration in Atlantic halibut (Hippoglossus hippoglossus); proteolytic liberation of free amino acids, and ion transport, are driving forces for osmotic water influx. J Exp Biol 2002, 205: 211-224.

[128] Wallace RA, Selman K. Oogenesis in Fundulus heteroclitus. I. Preliminary observations on oocyte maturation in vivo and in vitro. Dev Biol 1978, 62: 354-369.

[129] Stacey NE, Pandey S. Effects of indomethacin and prostaglandins on ovulation of goldfish. Prostaglandins 1975, 9: 597-608.

[130] Goetz FW, Garczynski M. The ovarian regulation of ovulation in teleost fish. Fish Physiol Biochem 1997, 17: 33-38.

[131] Thibault C. Ovulation. Contracept Fertil Sex 1999, 27: 605-613.

[132] Jalabert B, Breton B, Billard R. Dosage biologique des hormones gonadotropes de poissons par le test de maturation in vitro des oocytes de truite. Ann Biol Anim Biochim Biophys 1974, 14: 217-228.

[133] Santos AJG, Furukawa K, Kobayashi M, Bando K, Aida K, Hanyu I. Plasma Gonadotropin and Steroid Hormone Profiles During Ovulation in the Carp Cyprinus carpio. Bull Jap Soc Sci Fish 1986, 52: 1159-1166.

[134] Fostier A, Jalabert B, Terqui M. Action prédominante d'un dérivé hydroxylé de la progesterone sur la maturation in vitro des ovocytes de la truite arc-en-ciel (Salmo gairdnerii)]. C R Acad Sci Hebd Seances Acad Sci D 1973, 277: 421-424. 
[135] Nagahama Y, Adachi S. Identification of maturation-inducing steroid in a teleost, the amago salmon (Oncorhynchus rhodurus). Dev Biol 1985, 109: 428-435.

[136] Thomas P, Trant J. Evidence that 17 alpha,20 beta,21-trihydroxy-4-pregnen-3-one is a maturation-inducing steroid in spotted trout. Fish Physiol Biochem 1989, 7: 185-192.

[137] Patino R, Thomas P. Characterization of membrane receptor activity for 17[alpha],20 [beta],21-trihydroxy-4-pregnen-3-one in ovaries of spotted seatrout (Cynoscion nebulosus). Gen Comp Endocrinol 1990, 78: 204 217.

[138] Pinter J, Thomas P. Characterization of A Progestogen Receptor in the Ovary of the Spotted Sea-Trout, Cynoscion Nebulosus. Biol Reprod 1995, 52: 667-675.

[139] Thomas P, Zhu Y, Pace M. Progestin membrane receptors involved in the meiotic maturation of teleost oocytes: a review with some new findings. Steroids 2002, 67: 511-517.

[140] Pinter J, Thomas P. Induction of ovulation of mature oocytes by the maturation-inducing steroid 17,20beta,21-trihydroxy-4-pregnen3 -one in the spotted seatrout. Gen Comp Endocrinol 1999, 115: 200-209.

[141] Zhu Y, Rice CD, Pang YF, Pace M, Thomas P. Cloning, expression, and characterization of a membrane progestin receptor and evidence it is an intermediary in meiotic maturation of fish oocytes. Proc Natl Acad Sci USA 2003, 100: 2231-2236.

[142] Zhu Y, Bond J, Thomas P. Identification, classification, and partial characterization of genes in humans and other vertebrates homologous to a fish membrane progestin receptor. Proc Natl Acad Sci USA 2003, 100: 2237-2242.

[143] Yamashita M. Toward modeling of a general mechanism of MPF formation during oocyte maturation in vertebrates. Zool Sci 2000, 17: 841-851.

[144] Bobe J, Maugars G, Nguyen T, Rime H, Jalabert B. Rainbow trout follicular maturational competence acquisition is associated with an increased expression of follicle stimulating hormone receptor and insulin-like growth factor 2 messenger RNAs. Mol Reprod Dev 2003, 66: 46-53.

[145] Bobe J, Maugars G, Nguyen T, Jalabert B. Specific gene expression profiles are associated with follicular maturational competence acquisition in rainbow trout (Oncorhynchus mykiss). Fish Physiol Biochem 2003, 28: 309-311.
[146] Bobe J, Nguyen T, Jalabert B. Targeted gene expression profiling in the rainbow trout (Oncorhynchus mykiss) ovary during maturational competence acquisition and oocyte maturation. Biol Reprod 2004, 71: 73-82.

[147]Zohar Y, Breton B, Fostier A. Short-term profiles of plasma gonadotropin and 17 alpha-hydroxy,20 beta-dihydroprogesterone levels in the female rainbow trout at the periovulatory period. Gen Comp Endocrinol 1986, 64: 189-198.

[148] Jalabert B, Baroiller JF, Breton B, Fostier A, Le Gac F, Guiguen Y, Monod G. Main neuroendocrine, endocrine and paracrine regulations of fish reproduction, and vulnerability to xenobiotics. Ecotoxicology 2000, 9: 2540.

[149] Celius T, Haugen TB, Grotmol T, Walther BT. A sensitive zonagenetic assay for rapid in vitro assessment of estrogenic potency of xenobiotics and mycotoxins. Environ Health Perspect 1999, 107: 63-68.

[150] Denslow ND, Chow MC, Kroll KJ, Green L. Vitellogenin as a biomarker of exposure for estrogen or estrogen mimics. Ecotoxicology 1999, 8: 385-398.

[151] Latonnelle K, Menn Fl, Bennetau-Pelissero C. In vitro estrogenic effects of phytoestrogens in rainbow trout and Siberian sturgeon. Ecotoxicology 2000, 9: 115-125.

[152] Monod G, Rime H, Bobe J, Jalabert B. Agonistic effect of imidazole and triazole fungicides on in vitro oocyte maturation in rainbow trout (Oncorhynchus mykiss). Mar Environ Res 2004, 58: 143-146.

[153] Breton B, Quillet E, Jalabert B. The control of reproduction and sex in fish in aquaculture. Prod Anim 1996, Hors série, 50 ans de recherches en productions animales, p 1726.

[154] Chourrout D. Thermal induction of diploid gynogenesis and triploidy in the eggs of the rainbow trout (Salmo gairdneri Richardson). Reprod Nutr Dev 1980, 20: 727-733.

[155] Chourrout D. Pressure-induced retention of second polar body and suppression of first cleavage in rainbow trout: Production of alltriploids, all-tetraploids, and heterozygous and homozygous diploid gynogenetics. Aquaculture 1984, 36: 111-126.

[156] Beardmore J, Mair G, Lewis R, I. Monosex male production in finfish as exemplified by tilapia: applications, problems, and prospects. Aquaculture 2001, 197: 283-301.

[157] Maisse G, Breton B. Contrôle photopériodique de la saison de reproduction chez les salmonidés. Prod Anim 1996, 9: 71-77. 